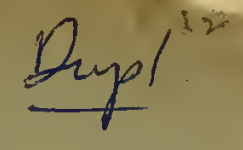

\title{
DESCRIPTIVE NOTES ON FIBRES,
}

PREPARED FOR THE

\section{GREATER BRITAIN AND PARIS EXHIBITIONS,}

\author{
FRoM
}

PLANTS (INDIGENOUS AND EXOTIC)

CULTIVATI I. IN TIE

MELBOURNE BOTANIC GARDENS

BY

WILLIAN ROBERT GUILTOYLI, DIRECTOR.

MAROH, 1899.

p 633.5

@y Antloxity:

G 956

ROBT. S. BRAIN, GOVERNMENT PRINTER, MELBOURNE. 



\section{DESGRIPTIVE NOTES ON FIBRES,}

PREPARED FOR TIIE

GREATER BRITAIN AND PARIS EXHIBITIONS,

FROM

PLANTS (INDIGENOUS AND EXOTIC)

CULTIVATED IN THE

MELBOURNE BOTANIC GARDENS

B Y

WILLIAL ROBERT GUILFOYLE, IJIRECTOR.

MAROH, 1899.

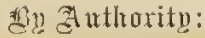

ROBT. S. BRAIN, GOVERNMENT PRINTER, MELBOURNE.

2296.

MUSEUM OF VICTORIA

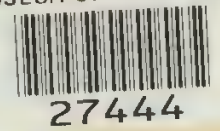





\section{PREFATORY NOTE.}

HaViNG been requested by the Grovermment of Victoria to supply, as speedily as possible, a collection of fibres for the Greater Britain and Paris Exhibitions, also to submit a descriptive list of the plants yielding them, giving also particulars regarding the methods adopted or initiated by me for preparing the samples, I have to state that, although a liberal sum of money was allowed me for the purpose, time was so much restricted that, although the collection comprises 119 distinct specimens, I regret it is not so extensive as I should have desired.

While the Anstralasian colonics are rich in regard to indigenous plants that yield varions fibies of a most useful character, it will be also interesting to culturists to know that botl the climate and soil of Victoria are well adapted for successfully growing nearly all of the well-known fibre plants of the Old World, as well as those of temperate America and the Cape-or rather, South African colonies. The whole of the specimens enumerated in the subsequent pages (and fully rescribed also on the labels attaclied to each in the large show-case) were obtained from such indigenous and introduced plants as vere grown in our Melbourne Botanic Gardens, where they are used, in the various groupings, for either scenic effect or for educational purposes.

Experts in Europe, America, and elsewhere will probably determine the various uscs to which this collection can be put; indeed Professor Charles Richards Dodge, special agent of the U.S. Department of Agriculture, Washington, * and Sir Fredk. Abel, director of the Imperial Institute, London, have already commented extensively and most favorably on many of the kinds now enumerated. I have had the honour of supplying similar collections of fibres to many Exhibitions, notably the Centennial of Philadelphia, 1876 (and the preparatory one liere in 1875); the Paris Universal, 1878 ; Mclbourne International of 1890 ; that of Amsterdam, 1883 ; New Orleans, 1884-5; the Colonial and Indian, 1886; Jubilce International, Adclaide, 1887; Melbourne Centennial, 1888-9; the Now Zcaland Exhibition of the samo year; and last, not least, to the Inperial Institute, London.

\section{W. R. GUILFOYLE,}

Mareh, 1899.

\section{Director Botanic Gardens, Melbourne.}

* Vide his most interesing volume of $\$ 61$ pages, entitled Useful Fibre Plants of the IForld, pablished by the American Guvernment during last year. 

DESCRIPTIVE NO'LS ON FIBRES, PREPARED FOR THE GREATER BRITAIN AND PARIS EXHIBITIONS, FROM PLANTS (INDIGENOUS AND EXOTIC) CULTIVATED IN THE MELBOURNE BOTANIC GARDENS,

\section{By William Robert Guilfoyle, Director. \\ March, 1899.}

I.-Abutilon Bepfordianum (St. Hilaire). "Duke of Bedford's Lantern Flower." Order Malvacea. Brazil.

This splendid slurub grows very freely in Victoria, New South Wales, and Queensland, and may be profitably cultivated, especially with irrigation. 'The fibre is of good quality, and very simply prepared by macerating the shoots in the same way as "jute" (Corchorns capsularis), \&c. For yonng branches, thirteen days' soakage are sufficient; older bark requires several days longer. Fibre suitable for whipcord, fine matting, paper, and perhaps textile fabrics.

II.-Abutilon coccineum (Hort). "The Red Lantern Flower." Order Malvacece. Garden origin.

Prepared by maceration for seventeen days, but stems from which present sample was prepared were old. If cultivated as a fibre plant would no doubt equal A. striatum.

III.-Abutilon Molle (Swoet) syn. Sida mollis (Ortega). "Soft-leaved Lantern Flower." Order Malvacca. Peru.

Like most of the other species of the genus, this plant, which is an ornamental yellow-flowered slurub, is of quick growth, and yields both a valuable bast and fibre. These are of a strong, soft, and beautiful quality, and are easily prepared by the simple process of maccration for tivelve days. Snitable for matting, paper, \&e.

IV.--Abutilon striatum (Dickson). "Streaked Lantern Flower." Order Malvacec. Brazil.

A handsome quick-growing shrub of slender habit, readily available for cultivation in the colonics, and, like the foregoing species, yiclds a valuable fibre by marceration for seventeen days. 
V.-Abutilon Thompsonir. "Thompson's Variegated Lantern Flower." Order Malvacee. Garden origin.

'Twelve days' maceration, stripped, and then scraped. Fibre supposed to be superior to A. molle and A. striatum.

VI.-Ábutilon Venosum (Lemaire). "Veined Lantern

Flower." Order Malvacece. Mexico.

A very ornamental species, of robust liabit, and yiclds a superior fibre. Two crops of "canes" may be rcalily obtained in a year in fairly good soil by proper managoinent. Twelve days' maceration, stripped, and then scraped. Suitable for fishing lincs, textile fabrics, \&c.

VII.-Agave Americana (Linnæus). "American Aloe," "Toddy Lily," or "Pita Hemp Pllant." Order Amaryllidece. Tropical America.

Agave Americana, under the various names of "Century Plant," "Mexican Aloe," "Spanish Aloe," "Carata," or "Pita," is the most common and best known of the genus in this country. 'The drought-enduring character of the plant is extraordinary, and it will thrive in any soil, rich or poor. Barren waste lands in arid regions might be planted with profitable results. After, say, from six or seven year's, the Agave will gro on yielding annual crops of huge fleshy leares, 4 to 6 fect in length, for a term possibly of eight or ten years longer. Spon observes that-" "The culture of the plant is being extended in America, but not to the extent it deserves." The product is often known commercially as "Agave thread," and is cxported for admixture sometimes witl Manilla hemp. The fibre may be separated by bruising the leaves, macerating, or by a boiling or stcaming process. Most effective machinery for the preparation of it has been used of late ycars in Mexico and other parts of America, by the aid of which it can be made realy for cleaning a few hours after the leaves have becn ent, or in the sarne way that "A gave sisalina" and other" species or varieties are prepared at the Bahamas and Yucatan. Professor C. R. Dodge says that - "In Mexico the common kind is ntilized in the manufacture of ropos for use in the mines, and, in some cases, for the rigging of ships." In South America it has been nsed for large eables. Humboldt mentions a bridge in Quito, with a span of 130 feet, constructed of ropes made of this fibre, some of them 4 inches in diameter. The name "Pita" follows it to Spain and Sicily, where it is nsed for cordage and mats." Dr. Forbes Royle says - "That it has been found superior in strength to either coir, jutc, or sum-hemp. In a trial of strength, near Calcutta, the 
tests were made with ropes 1 fathom long and 3 inelıes in cirelumference, with the following results:-The Agave or "Piı" broke in a strain of $2,519 \frac{1}{2} \mathrm{lbs}$; coir, $2,175 \mathrm{lbs}$; jute, $2,456 \frac{1}{2} \mathrm{lbs}$; and sunn-hemp, 2,269!1 los. In an experiment with Russian hemp and "Pita" (stout cords), the first-named broke with $1601 \mathrm{bs}$. weight, and the latter with $270 \mathrm{lbs} . "$ "These experiments," Professor C. R. Dodge adds, " show the great strength of the fibre, which is worthy of more extended cultivation and employment in the arts." Fibre prepared by boiling for six hours, put through rollers, and then seraped.

VIII.-Agave Americana (Linnæus) variety Longifolia. "Long-leaved Variegated American Aloe." Order Amaryllidece.

Fibre prepared by boiling for six hours, put through the rollers, and seraped. It is longer in staple than A. Americana, and quite equal to it in strength.

IX.-Agave Amuricana (Linnæus) variegata. "Variegated American Aloe," "Toddy Lily," or "Pita Hemp Plant." Order Amaryllidece. Tropical America.

Yields same quantity of fibre as the normal green-leaved form, and is more casily prepared. As in the case of the New Zealand Flax Plant (Phormium tenax), the variegated-leaved variety produces stronger and softer fibre. Prepared by boiling for six hours, put through rollers, and thon scraped with blunt knives.

\section{X.-Agave angustifolia (Haworth). "Narrow-leaved Agave." Order Amaryllidere. St. Helena.}

A narrow-leaved species of the genns, producing a very strong fibre, which is readily prepared by boiling for six hours, leaves placed through the rollers, and then seraped.

XI.-Agave atrovinens (Karwinsiki) syns. A. Jacobiana (Salm Dyek). A. Salmiana (Otto). The "Magney Blando" of Mexico. Order Amaryllidew. Mexico.

Fibre propared by boiling for six hours, put through the rollers, and then scraped.

"Specimens shown in the Mexican exhibit at the Paris Exposition of 1878 elosely resembled the fibre of A. Americana, white, wavy, of medium strength. Fibre from a plant of A. Salmiana, growing in the United States Botanic Garlen, extracted by the Department, was coarse, harsh, and wiry, without any of the characteristics of the Mexican samples." (Useful Fibre Plants of the World, Professor C. R. Dodge.) 
XII,-Agave Densiflora (Hooker). "Dense-flowered Agave." Order Amaryllidece. Mexico.

A valuable species, of moderately quick growth, furnishes a useful fibre. Prepared by boiling for six hours, forced through the rollers, and scraperl.

XIII.-Agave Geminiflora (Ker) syn. Littæa geminiflora (Tagliabue). "Twin-flowered Agave." Order Amaryllidece. Peru.

Fibre of strong quality. Prepared by simply scraping the leaves in the raw green state.

XIV.-Agave Ghiesbrechtil (C. Koch). "Ghiesbrecht's Agave." Order Amaryllidece. Mexico.

Leaves boiled for six hours, placed through the rollers, and then scrapcd. Equal in texture, and not unlike A. Rumphii.

XV.-Agave Ixthi (Karwinski). "Istle Hemp Plant." Order Amaryllidece. Mexico.

Prepared by boiling for six hours, leaves drawn through the rollers, and scraped.

XVI.-Agave Karatro (Miller). "Karatto." Order $A m a_{\text {- }}$ ryllidece. Mexico.

The fibre strong. Prepared in the same way as other species of the genus, by boiling for six hours, and then the usual rolling and scraping process.

XVII.-Agave lophantha (Scheide) var. cœrulescens. Sym. A. cœrulescens (Salm Dyck). "Bluish-leaved Crest-flowered Agave." Order Amaryllidec. Mexico.

Leaves boiled for four hours, and then scraped, easily prepared. Samplc obtained from fifteen leaves. Fibre not so fine as other Agaves, but very strong and wiry.

XViII.-Agave Mexicana (Lamarck). "Mexican Agave." Order Amaryllidece. Mexico.

This species affords a very good fibre, in texture like that of the "American Aloe" (Agare Americaua). Preparation same as A. Karatto.

XIX.-Agave Rigida (Miller). The "Chelem" of the Mexicaus. Oriler Amaryllidea. Mexico.

Preparation same as A. Karatto. 
XX.-Agave Rumphil (Hasskarl). "Rumpli's Agave." Order Amaryllidece. Mexico.

Preparation same as A. Karatto.

XXI.-Alpinia corulea (Bentham) syn. Hellenia cœrnlea (R. Brown). "Blue shell Flower" or "Queensland Ginger." Order Scitaminece. New South Walcs and Queensland.

Fibre prepared by boiling for twelve hours, and then scraped. Similar in texture to that of A. nutans, somewhat fincr, and not so long.

XXII.-Alpinia nutans (Roseoe). "Indian Shell Flower." Order Scitaminece. East Indies.

A liardy perennial belonging to the same order as the Ginger plant of commerce. The flowers are remarkably beautiful. It yields a fine fibre, which is easily prepared by boiling for twelve hours, and then seraping.

\section{XXIII.-Althea Narbonnensis (Pourret). "Narbonne Mallow." Order Malvacece. Europe.}

'The mode of preparation is by maceration for ten days, and then scraping. Fibre similar to that of Lavatera maritima.

XXIV.-Anigozanthos Flavida (Redoute). "Yellow Sword Lily" or "Kangaroo-foot Flower." Order Hcemodoracece. Western Australia.

'This hardy perennial-not unlike some of the Iridea in habit - sends up a number of thick sword-shaped leaves, about an inch wide, and from 18 inches to $2 \frac{1}{2}$ feet in height. The fibre obtained is of a chocolate-brown colour, of fair strength and texture. The mode of preparation is by boiling for two hours, or until the outer fleshy coating of the leaves is sufficiently digested to admit of easy removal by scraping with a blunt knife. The plant thrives in a sandy loam, and may be propagated in unlimited quantities by division of the roots, and from seeds. 'Tle fibre appears to be similar in texture to Musa Eusete.

XXV.-Anigozanthos rufa (Labillardiere). "Reddish Sword Lily" or "Kangaroo-foot Flower." Order Hcomodoracece. Western Australia.

The same remarks apply to this as to the preceding species. 
XXVI.-Astelia Banksu. (A. Cunningham). "Otago Cotton Plant" or "Kowhara-whara." Order Liliacece. New Zealand.

A coarse tufted perennial, leaves from 3 to 5 feet long, $\frac{1}{2}$ to 1 inch broad, covered with a silky down. It is usually found growing on the branches of trees at their junction with the trunk, or on old stumps, \&c., but will grow freely when planted in the ground. The leares are traversed longitudinally by stont nerves, which furnish a coarse fibre of considerable strength. Prepared by boiling or steaming for about ten hours. "It is rich in fibre suitable for ropes, paper," \&c. "The fibre is of a dirty yellow colour, the 'filaments' excecdingly coarse and wiry, rather brittle when bent sharply, but of considerable strength when tested with a lateral strain." The specimen in the collection of the Department of Agriculture, Washington, was also prepared by me. (Useful Fibre Plants of the World, Professor C. R. Dodge.)

XXVII.-Beadcarnea gladca. (Lehmann). "Sea-greenleaved Beancamea." Order Liliacece. South America.

Produces a fibre of good quality. Prepared by boiling for six hours, and then scraping.

XXVITI.-Bahmeria nivea (Gandichand). "Chinese Grass-cloth Plant." Order Uricacece. Tropical Asia.

From this is produced that beautifnl creamy whito fahrie, known as "China Grass-cloth," which is frequently mistaken for silk, indeed the better qualitics of it are often sold as such in England and many parts of the Continent.

The Kew Bullefin, treating of the "Ramie" (said to be a variety of the above) industry, says :- "Few practical problems have consumed so much time and energy as the attempt to bring 'China-grass' and 'Ramie' into use for manufacturing purposes.

"Notwithstanding all tlie expenditure of mechanical skill and inventive ability, the conclnsion cannot be evaded that we are still as far off as ever from being able to place upon the market a finished product which will effectually compete with silk, flax, and the better qualities of cotton.

"The plants can be grown with the greatcst case. But when the problem of treatment is solved, the supply of the raw material will be limited to warm countries. The cultivation of 'Chinagrass' in temperate regions will never be able to compete successfully with that of 'Ramie' (or perhaps of China-grass) in the tropies. It is known that when ribbons can be produced sufficiently cheaply, these can be degummed and turned into 
filasse at a small cost. The whole question then still tmrns, as in 1888 , on the production of ribbons. We are still waiting for a decorticator which will not merely turn ont ribhons fit for further manufacturing processes, that has becn accomplished, but will turn out, say, half-a-ton a day at a small cost. 'T'ill this has been found, the planter cannot profitably deal with his crop, and the decrumming processes, now almost entirely dependent on handclean fibre from China, are paralyzed for want of a supply which will allow the finished product to compete with other fibres.

"The ribbons must be susceptible of being delivered to the degumming factories at a cost not exceeding $£ 7$ to $£ 9$ per ton. This would pay the planter if' he had a decorticator which wonld leave a profit. At present he cannot produce ribbons under £12 to $£ 15$ a ton.

"Then the degumming processes should turn out filasse at a total cost of $£ 36$ to $£ 40$ per ton. At this price the demand would be considerable, and a large and prosperous industry would result. To put the position in other words, filassc must be put upon the market at about $4 \mathrm{~d}$. per $1 \mathrm{~b}$. To use the words of one of the speakers in the discussion at the Society of Arts, "Unless it could be brought down to something like the price of cotton or flax, it was impossible to make any profit out of it." 'The Produce World says :-

"The time for planters in India and the East, generally, to seriously take in hand the production of ' Rhea' fibre has now fully arrived, and we hope, in the very near future, to receive more numerous inquiries from our readcrs as to the best means of disposing of preparcd filasse. For some time scveral factories in England and America have been engaged exclusively in manufacturing all kinds of textile fabrics from the fibre, and there are unmistakable signs that a fine future awaits the new industry. In addition to a profit obtainable from the preparation of the fibre, however, there are several other good points about 'Ramie' cultivation. Besides being perennial, the plant requires absolutely no cultivation beyond thinning out, and the thinned-ont plants may be at once replanted in new ground. The original root survives for 30 to 40 years; the leaves are greedily eaten by cattle, and are highly nutritious; and the best means of propagation are from root cuttings. Planters need lay out but little capital on this product, is the stalks are marketable withont degumming, or additional profits may be realized by doing the degrumming and fibrc extraction on the estrtc. 'Thus, on the lowest coinputation, a return of $£ 18$ pcr acre is certain, with the expenditure of the minimum of labour and capital.

"If actual results are requircd, here they are. Upon an estate in Mexico the out-turn of cleaned fibre, in 1896, was 1,936 tons, 
and tho priee obtainable in Now York was 250 dollars (£25) per ton. The total eost of eultivation and laying down in New York, ineluding $\mathfrak{E} 5,550$ (nearly $£ 3$ per ton) for earriage and insuranee, amounterl to 203,007 dollars (Mexiean), and the working eapital was increased to 233,007 dollars, by 30,000 dollars expended on maehinery. After deducting 27,830 dollars for eommissions, tho net profit reached 326,692 dollars, or 145 per eent. on the working eapital. Such results leave ample margin for repayment of interest upon cost of land, and aetnally make it possible to repay the purehase money within a very short time, and still have left an ostate bringing in a handsome profit, especially in countries where land is eheap."

The simple method adopted in preparing the present sample was as follows :-Bark stripped off the "eanes," scraped at onee, and soakedfor 24 hours in water, with a fair quantity of Sapo mollis well dissolved in it. I have found this treatment most effoetive in quiokly getting rid of the gummy matter. This mode is worthy of further experiment.

XXLX.-B(enneria macropmlda (D. Don). "Large-leavod Grass-eloth Plant." Order Urticacec. Himalayas and Burmah.

'I'he plant is of far more robust habit than the preeeding, and has frequently reached a height of 6 to 7 feet in our gardens.

Preparation samo as above.

XXX.-CAlEX PANictlata (Linnæus) syn. C. adpressa (R. Brown). "Close-spiked Sedge Grass" or "Hassoek Grass."

Order Cyperacex. Australia, New Zealand, Europe, and Asia.

'I'his species of Sedge is very eommon throughout Vietoria in low-lying swanpy grounds, and along river and ereek conrses. It yields a strong fibre, whieh is prepared by boiling for twelve hours, and afterwards scraping the leaves.

XXXI.-Carex Threticaulis (F. v. Mueller). "Roundstommerl Sellge Grass." Order Cyperacece. Vietoria, New South Wales, South and West Australia, and Tasmania.

Produees a very strong fibre, whieh is easily prepared, like the preeeding species.

XXXII.-Commersonta Fraseri (J. Gay). "Blackfellow's Hemp" or "Tio l'lant" of Australia. Order Sterculiacece. Victoria, New South Wales, and Queensland.

A good fibre when properly prepared. The blaoks of northern Now South Wales and Queensland prepare fishing lines and nets from the bast of this shrub, whieh is torn from the young branehos in a green state, and selaped with sea shells. 
"It yields a fine fibre suitable for matting and cordage, and a good quality of paper eould donbtless be made from it. The muselum specimen was obtained from the Victorian collection, Phil. Int. Exh., 1876, and was prepared by Mr. W. R. Guilfoyle. The fibre is quitc dark, duc probably to insufficient bleaching, but is strong and not very brittle; and, although the filaments are stiff, they exhibit under the magnifying glass a very fibrous nature, some of them being fine and lustrons ; is inferior to Hibiscus fibre. It measures betwcen 2 and 5 feet in lengtl.." (Useful Fibre Plants of the World, Professor C. R. Uadge.)

XXXIII.-Condyline australis (Hooker, fil.) syn. C. Forsteri (F. v. Mueller). "Forster's Palm Lily." Order Liliacece. New Zealand.

This noble plant attains an ultimate height of 40 feet under favorable circumstances. Its leaves afford a large percentage of excellent fibre, of finer texture than that of C. Banksii, thongh supposed to be not quitc so strong. It is prepared in a similar manner, but the weight of fibre to the scre would be very much greatel on accoult of the more robnst habit of the species. Under good cultivation the plants would begin to yield a profitable return after the third year, which would go ou increasing ammually for a considerable time. As the Cordylines produce secd in enormons quantities, and can be increased also by offshoots stuck in the open gromed, there is no limit to the numbers which may be propagated, so that a young plantation conld be always coming on to take the plaee of the old when the latter becume unprofitable. It must be remembered, tou, that a great extent of land eomparatively uscless, on account of partial inundation, could be profitably planted with Cordylines and kindred plants.

Prepared by boiling for six hours, then seraping.

XXXIV.-Cordylise australis var. Cookii (?). "Captain Cook's Palm Lily." Order Liliacea. New Zealand.

'The fibre from the leaves of this variety is very strong, and ensily prepared by boiling for six lours, and then seraping.

XXXV.-Cordyline australis var. lineata (?). "Lineleaved Palm Lily." Order Liliacece. New Zealand.

This, like many other kinds, yields a very strong fibre, prepared readily by boiling for six hours, and the usual seraping process. 
XXXVI.-Cordyma Banksil (Itooker, fil.). "Sir Joseph linnks' l'ahn lily." Order Liliacere. New Zealand.

'I'he leaves of this plant sometimes attain, when cultivaled, a length of 3 leot. 'The fibre is of superior quality to most of the New Zealland species on aceount of its long staple and great strength. In addition to being available for ropes, nuthing, Ee., the stont midrib of the leaf might be nsed in brush-making.

I'rofessor C. R. Dodge, of New York City, in his reprort to the Comnissioner of Agrienlure, 'T'he IIon. Wm. G. Le Duc, on the fibres cxhibited at the Philadelphia Exhibition, 1876, thus sposks of the sample of Cordyline Thanksii* fibre sent from these gatrlens:- "It is convertible into a good quality of paper. The fihre is from s! to 3 feet in lengih, struight, white, and glossy, but very still, resembling fibre of Yreca or $\Lambda$ gave. It is fully as strong as Yucen fibre, and would make oxcellent ropo of great tenteity."

'This plant wonld pay woll lor' enltivation, especially on irrigated land; muler these conditions two or even three stripplings of the onter lanves might be gatheres in a year. 'The preparation of the fibre is rery easy by boiling, nine honrs being suflicient to digest the fleshy coating of the leaves, which require seraping and very litulo heckling to separate the filaments.

XXXVII,-Compring Baumi (Tooker) syn. C. nutans. (A. Cmmingham). "Baner's I’alin Lily." Order Liliacece. Norfolk lslankl.

A fino brom-leaved species which yields a fibre ol fair quality. Trepantion, simply boiling for three hom's and afterwats serapinc. 'The lenves attain a length of 2 feet or nore, and are olten 3 inches in width.

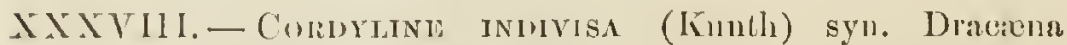
indivina (Kunth). The "Toi," "Ti-plant," "Tikapu," or" "Tow:ai." Order Lilincer". New Zealand.

A tall-growing species, with broud rigirl leaves. It yiolds a goot fibre. P'reparod by hoiling for six honrs, \&e., \&e.

XXXIx.-Condrane Sturun (T. Kirk). "Sturm's Palm Lily." Order Liliecere. New Kenland.

loaves of sample boiled for three hours, and seriped.

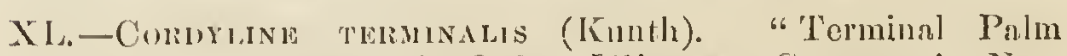
Lily" or "Ti Plant." Ordor Liliacece. Common in Now Sonth Wales, Queensland, Polynesia, \&c. se.

A fino silky filne, easily prepared by boiling for six hours, \&c.,

* Erroneonsly labelled C. punilio in the collection sent to Pliladelphia, 1876. 
XLI.-Condyline teminalis (Kunth) var. cannofolia (Bentham). Syn C. cannefolia (R. Brown). "Cammaleaved Palm Lily:" Order Liliacere, New South Wales and Queenshand.

A handsome very broal-leaved variety of the species, attaining a height of 8 or 10 feel. The leaves were boilcl for twelve. lours, and then seraped.

XLII.-Crpmus Lucious (R. Brown). "Shining Galingale Rush." Order Cyperacea. Victoria, New South Wales, Queensland, North and South Australia, and 'Tasmania.

'This tufted bog plant is found all over Anstralia and Tasmania, with the exception of the westcrn portion.

The fibre was preparcd by a boiling process.

\section{Xlim.-- Dasylimion gladcopmyludur (Hooker). "Glaucons Dasylirion." Order Liliacee. Mexico.}

The fibre obtained from this hardy-evergreen plant is strong and finc. Prepared by boiling for six hours, and then seraping. Two crops of leaves per ycar could be obtained in Victoria.

Xliv.-Dianelaa corulea (Sims). "Paroo Lily." Order Liliacece. New South Wales and Queensland.

Fibre similar to that of D. revoluta, and as casily prepared by boiling for three hours.

XLV.-Dranella Exligans (Kunth). "Elcgant Native Flix Lily." Order Liliacce. Victoria and 'Tasmania.

Sample of fibro produced is not nearly so strong, I think, as those obtained from other species. It is, however, very fine in texture, and is easily prepared by simply plaeing tho leaves in hot water for one hour, and then seraping.

XLVI.-Dianelda I, devis (R. Brown) syn. D, longifolia (R. Brown). "Smooth-leaved Flax Lily." Order Liliacea. Victoria, New South Wales, Quecnsland, South Australia, and 'Tasmania.

A pretty tufted herbaceous peremial, which bears large panicles of cocrulean-l,lue flowers, succeeded by large globnlar shining blue berries, which render the plant far more attractive than when in flower. The fibre is prepared by boiling the fully developed lcaves for two or three hours, or until tirey are sufficiently softened to admit of the easy removal of the cuticle by scruping. Very young leaves only require boiling for an hour. It is of a 
fino silky toxtaro, and might bo male into twine, fishing linos, de. 'The $A$ borignos lomerly platited tho louves of this mul other' spocies indo baskets, and also proparod fishing nots and linos from 1.110111.

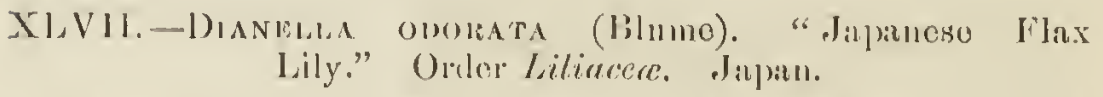

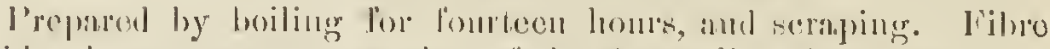
ovidently not as shomg as that of the Anstralian D)iancllas.

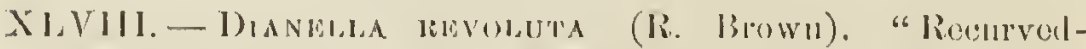

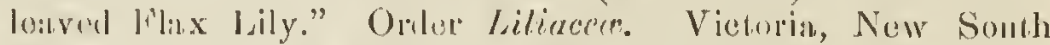

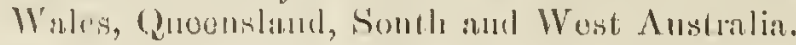

Very phentilully distributed thomblont Victoria, and thrives in lonse sambly soils. 'I'he present sanple, althongh short, is, connpared with some otdore specios, very strong. l'rocess of preparation, hoiling lon throo lours, and sermping.

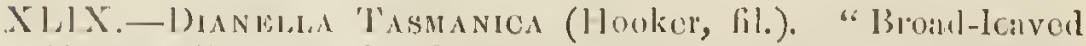
Native Flax lily." Orilor Lilieceed Victoria, Now South Wialos, and 'Thaminia.

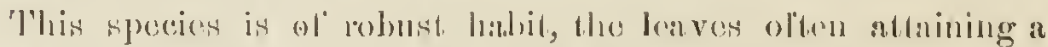
longth of more than of foot. In its wild state it is gencrally

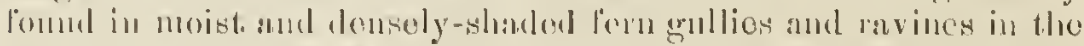
sulp-alpino districts of Victorian and 'Tasmantan, frequently on tho

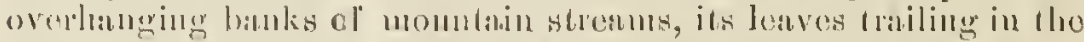

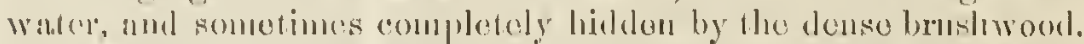

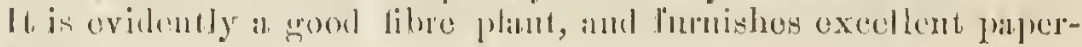
stock.

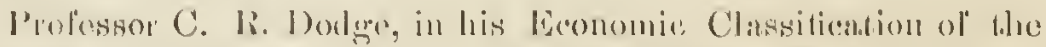

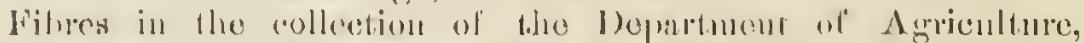

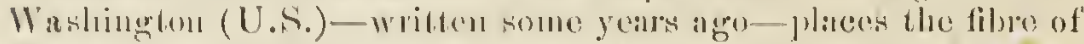

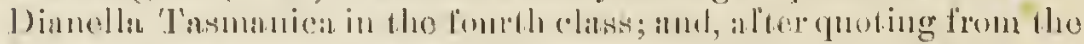

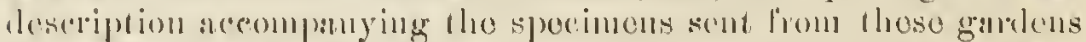

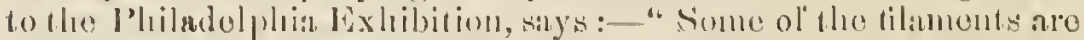
white and brilliant, it is quito strong, a fow twistod together ro-

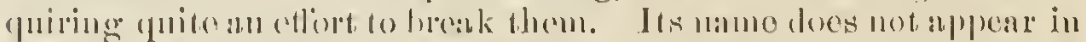

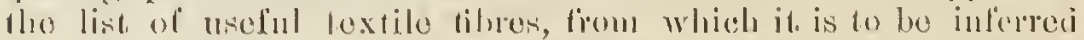
it has not hithorto been kinown als a libre-producing phant of my villue."

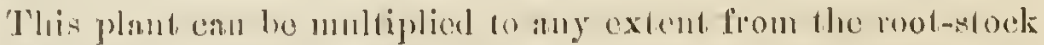

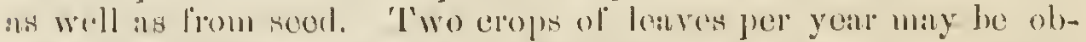
tained with oase: it thrives in any fairly grool soil, but attains

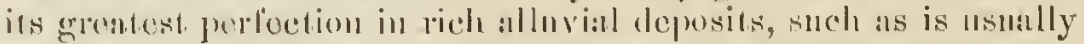

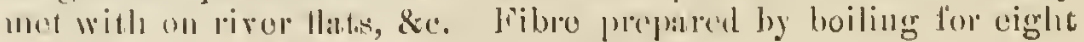

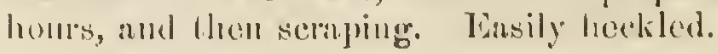


L.-Dierama rulcherrma (Bakor) syn. Sparaxis puleherrima (Hooker, fil.). "Prido of Katberry" or "Wand-flower." Ordor Iridece. South Afrion.

Fibre ensily prepared by boiling for two hours, and liko Iris ochrolcuea. May be valuable for' cordage, de. 'Thlo corms ineloase vory rapidly, and after' two yoars from the time of planting largo tufts of leafage aro produced. 'Two erops ean be obtained per year.

LI.-Donbeya Natalensis (Sonder). "Cape Wedeling Flower." Order Sterculiacece. South Afriea.

A beautiful flowering shrub or small troe, harly, and of quiek growth in the Australian eolouies. The bark furnishes by maeeration a very good fibre, suitable for ropes, corlage, saeking, Se. Fibre prepared by maeoration-young branehes, fivo weeks; old branches, six to eiglit weeks.

Litr.-Doryantues excelsa (Correa do Serra). "Now South Walos Spear Lily." Order Amaryllidere. Now South Walos and Queensland.

This plant elosely resembles the Fureraa (Fonroroya) gigantea of Tropieal Amcriea in appearaneo, and is often mistaken for it by tho uninitiated when not in flower. Like the Furcran, the leaves are rieh in fibre, of great strength, hut somowhat coarser. With proper appliances, however, it might possibly bo utilized for eloth, ropes, \&c., whilst the rofuse eould be converted into paper or used for stuffing mattresses, \&e. The present sample was prepared by boiling for a period of eight hours, and afterwards the usual scraping prooess. 'I'he plaut ean be propagated by division of the roots or from sech, whieh is prodnood in great abundauce.

IiIT.-Doryanthis Palmeri (Iill). "Palmer's Spear Lily" or "Quoonsland Rook Lily." Order Amaryllidece. Queonsland.

The prineipal differenee between this and D. excelsa is in the inforesncnce, which in D. oxcelsa is borne in a dense terminal corymboso panicle, whilst in D. Palmeri tho paniclo is elongatod to 4 feot or more, the weight of the infloresecnco of ten causing the flower stem to assume a droopiug aluost horizontal position. 'The gamo romarks apply to the quality of the fibro, oultivation, $\&$ e., as to tho other species hero deseribed.

Fibre prepared by boiling for twelve hours, placed through tho rollers, and then seraped.

2296. 
LIV. - Doryanthes Gullfoylei (Bailey). "The Giant Queensland Spear Lily." Order Amaryllidece. Qucensland.

Doryanthes Palmeri was hitherto considered to be the most gigantic and showy Amaryllid discovered in Australia, but it is eclipsed in size and beanty by this later discovery. The leaves and flower spikes are of hnge proportions. Leaves 9 fcet long, over 8 inches in width, and of a brilliant green. From the base of the flower stalk (which is $15 \frac{1}{2}$ inches in circumference) to the apex of the inflorescence is $16 \mathrm{ft}$. $2 \mathrm{in}$. Of this, no less than $7 \mathrm{ft}$. $8 \mathrm{in}$. forms a compound spike of rich crimson Amaryllis-like florets, cach 4 inches in length, $2 \frac{1}{2}$ inches broad (numbering 100 or more), supported by $8 \mathrm{ft}$. 6in. of stalk. Fibre prepared by boiling for twelve hours, then scraping after being placed through the rollers to squeeze out the gummy substance.

LV.-Doryanties Larkini (C. Moore). "Larkin's Spear Lily." Order Amaryllidece. Northern New South Wales and Quecnsland.

A very finc ornamental species. Quality of fibre, cultivation, \&c., same as the three preceding.

LVI.-Dracena Draco (Linnons). "Dragon's Blood Trec" of 'Tencriffc. Order Liliacece. Canary Islands.

'The stem, like the closely-allied Australasian Cordylines, becomes ramified by age into many leafy hcads. It attains to enormous proportions in its native habitat, as Humboldt tclls us, but in our colonies is very slow of growth. The fibre from the leaves assimilates closely to Yucea fibre, and is prepared in a similar manner.

\section{LVII.-EliEagnus JaPONICA. "Japanese Oleaster." Order Elceagnacece. Japan.}

'This, like several other now fibres mentionod in the list, was prepared by simply stripping the bark off the branches, and scruping the raw material. It furnishes a bast not unlike that of Dombeya Natalensis.

LVIII.-Furcrea (Fourcroya) gigantea (Ventenat) syn. Agave foctida (Linnaus). "Giant Fibre Lily" or "Mauritius Hemp." Order Amaryllidea. Tropical America.

This magnificent Amaryllid attains to great perfection in A ustralia, although in our own colony-Victoria-severe frosts damage the leaves to some extent. This, however, is no detriment to the fibre contained in them. It is extracted in a similar 
manner to Agave or "Pita" fibre, whieh it elosely resembles. The present sample has been prepared by a boiling process whieh extended over a period of ten lours, plaeed through the rollers, then seraped and heekled. Several experts say "that the fibre of F. gigantea is very like the sisal hemp of commeree, and donbtless is often so ealled."

Dr. Ernst, in the eatalogue of the Venezuelan Department (Phil. Int. Exh., 1876), states that-" The fibre is very strong, and is used for eordage and gunny bags. It is prepared in the same manner as sisal hemp. Samples of the Venezuelan speeimens are dyed in aniline to show that it will take colour."

Professor C. R. Dodge, in his valuable work, Useful Fibre Plants of the World, says:- "The plant is grown largely for fibre at St. Helena and Mauritius, and in the London market the produet is known as Mauritius hemp. F. gigantea is supposed to have been introdueed from South Ameriea to Mauritius about 1790. It has evidently found a congenial home there, for, without any effort on the part of man, it has eovered waste lands and abandoned sugar estates to suel an extent as to lay the foundation of a eonsiderable fibre industry. The leaves are often 8 feet in length, and from 6 to 7 inehes in breadtl. The pulp of the leaves when crushed gives off a strong pungent odour, and hence this species is sometimes ealled the frotid aloe. 'The juice is strongly corrosive and soon aets upon wrought iron; it is said to produee less effect on cast iron, while it is practieally inoperative on brass and copper. 'The plant grows in all soils and up to an elevation of 1,800 feet above the level of the sea. It has, however, more generally disseminated itself on the lowlands near the eoast, and on a few abandoned sugar estates that have beeome too dry for eave enltivation."

Lix.-Furcraa (Fourcroya) Bednegitausi (C. Koch). "Bedinghausen's Giant Lily." Order Amaryllidece. Mexieo.

Prepared by boiling for two hours, rolled, and then scraped. Easily prepared. Fibre very elastie when wet.

I.X. - Gahnia Psittaconcus (Labillardiere) syn. Cladium psittacormm (F. v, Mueller). "Vietorian Ginnt Grass" or "Parrot Rush." Order Cyperacece. Victoria, New South Wales, Queensland, Sonth Australia, and 'Iasmania.

Usually found in the uplands and on banks of crecks, ice. It clusely resembles $G$. Radula in appen'anee, and the remarks in the deseription of that species apply equally to this as a fibre plant.

Leaves boiled for 24 hours, and then seraped.

2296. 
LXI.-Gahnia Radula (Bentliam) syn. Cladium Radula (R. Brown). "Cutting Grass," "Black Reed," or "Briekmaker's Grass." Order Cyperacece. Victoria, South Australia, and Tasmania.

A coarse tufted perennial, very plentiful on poor rather wet land, especially near the coast. It is chiefly valued by the settlcrs as a thatching material, for which purpose it is well adapted, lasting for several years. As a fibre-plant it may be of no value, the filaments being harsh and brittle; but as a paperstock it may prove of commercial importance, even as an admix. ture with other material. It can be obtained in almost unlimited quantity in our colony. Prepared by boiling for 24 hours, and then scraping.

LXII.-Grewia occidentalis (Linnæus). "Afriean Star Bush" or "Kaffir Hemp Bush." Order Tiliacece. Africa.

A quick-growing evergreen shrub, which bears a profusion of bright purple aster-like flowers of great beauty. The bark of the yolng branches furnishes by maeeration a strong fibrous bast, which might be manufactured into ropes, corlage, \&c. The plant thrives in Australia, and is easily propagated both by seed and from cuttings, the latter rooting freely out of doors, if put in during the autumn season. The young branches take 18 days, and the older 27 days, to macerate.

"A whitc fibre of great strength extracted by retting, and much used by the Kaffirs." (Spon.)

LXIII.-Hibiscus Hembaceus. (Vell). "Herbaceous Rose Mallow." Order Malvacea. Brazil.

Prepared by maceration for a period of 20 days, sample obtained from inferior material. May yet prove a good filure plant if cultivated for that purpose. Like the Bohmerias it increases rapidly during our suminer, and dics partly down in winter. Two crops of "canes" per year can be relied upon, first crop 3 feet, second erop 2 feet, stems.

LXIV._Hrbiscus Heterophyctrs (Ventenat.) "Queensland Sorrcl Tree" or "Batham." Order Malvacece. New South Wales and Queensland.

A tall stout-branched shrub or small tree. Flowers large, white, witl crimson centre. The bark affords a fibre very similar in quality and appearance to that prepared from $H$. splendens. Prepared by maceration-young branches, 16 days; old branches, 6 days longer. The present sample was obtained from very unsuitable wood. 
LXV.-Hibiscos Sxriadus (Linnæus) syn. Althæa Frutex (Hort). "Syrian Rose Mallow." Order Malvacea. Syria.

This well-known shrub, it must be admitted, affords a beautiful white fibre of considerable strength, and could be worked into a very useful fine-cord material. The plant succeeds well in most parts of Australia, and is readily propagated by cuttings, which root freely out of doors in sandy soil. Fibre prepared by maceration for a period of 35 days, and then scraped with blunt knives.

LXVI.-Hoheria populnea (A. Cunningham). "Ribbonwood of Otago." Order Malvacece. New Zealand.

A graceful tree, not unlike the "Aspen" (Popnlus tremula, Linnæus), attaining a height of 60 to 70 feet in favorable situations. The bast furnished from the branches and from young trees is very beautiful, being of a delicate lace-like texture, very strong and glossy. It is suitable for weaving into textile fabrics, and can bc also utilized for matting, ropes, cordage, \&c. The mode of preparation adopted was maceration, which occupied from 12 to 15 days.

\section{LXVII.-Hypoxis LONGIFolia (Baker). "Long-leaved Hypoxis." Order Amaryllidece. South Africa.}

Fibre prepared by boiling for two hours. Very little trouble as regards preparation. Fibre not unlike that of Dianella. elegans.

LXVIII.-IRIS OCHROLEUCA (Linnæus) syn. Iris giganter (Carriere). "Yellowish-white Iris." Order Iridece. Asia Minor.

Fibre produced for the first time. Prepared by simply placing the leaves in boiling water for one hour, and then scraping. Well worthy of cultivation, and trial as a fibre plant.

LXIX.-Junces communis (E. Meyer). "Common or Candle Rush." Order Juncacece. Australia, Tasmania, New Zealand, Europe, \&c.

This cosmopolitan species of rush may be obtained in euormous quantities in Australia. It makcs excellent paper matcrial. The fibre was prepared by boiling for eight hours, and then scraped.

LXX.- Juncus Maritinus (Lamarck). "Sea Rush" or "Common Coast Rush." Order Juncucece. Australia, Tasmania, \&c.

This, like J. communis (E. Meyer), has a very wide geographical range, "being common in maritime marshes and moist sandy tracts in temperate regions." It forms a good paper-stock, 
and can be obtained here in large quantities. Fibre prepared by boiling for sixteen hours, then simply run throngh the rollers, dried, and heckled. No scraping required.

LXXI.-Juncus Palitidus (R. Brown) syn. J. vaginatus (E. Meyer). "Pale-green Rush" or "Toolim." Order Juncacece. Australia, Tasmania, and New Zealand.

A tall-growing and stout rush, which may be obtained in large quantities in almost any part of our continent. It is supposed to be an excellent paper material, and it furuishes also a fibre of considerable strength. Baskets and other useful household things, sucli as picture-frames, \&c., are sometimes made of the leaves by settlers, both in a peeled and unpeeled state. The preparation of the present sample was by boiling for some hours, or until the cuticle came away easily by scraping.

LXXII.-Kniphofia aloides (Mœnch) syn. Tritoma Uvaria (Ker). "Aloe-like 'Torch Lily" or "Flame Flower." Order Liliacece. South Africa.

The fibre from this species is readily obtained, and shows a sample of good quality. Prepared by boiling for two hours, and then scraping.

LXXIII. - Kniphofia Aloides (Mœneh) var. glaucescens. "Glaucous-leaved Toreh Lily" or" "Flame Flower." Order" Liliacece. South Africa.

Preparation the same. Fibre similar to $K$. grandiflora.

LXXIV.-Kniphofia aurea syn. Tritoma aurea. "Goldentinted Torch Lily" or "Flame Flower." Order Liliacece. South Africa.

This species is rich in fibre material. Easily grown, and produces a wealth of long foliage. The fibre is easily prepared after boiling for two hours, then lightly scraped with blunt knife.

LXXV.-Kniphofia grandiflora syn. Tritoma grandiflora. "Large-flowered. Torch Lily" or "Flame Flower." Order Liliacece. South Africa.

Sample prepared from the matured leares of the plant. Probable yield $1 \frac{1}{2}$ tons per acre, two crops per year equal, say, 3 tons. The commercial value quoted to me from England at from $£ 17$ to $£ 17$ 10s, por ton.

Method of preparation, boiling the leaves for two hours, \&c., same as above. 
LXXVI.-Kiniphofra Rooperi (Lemaire) syn. Tritoma Rooperi (T. Moore). "Rooper's 'Torch Lily" or "Flame Flower." Order Liliacece. South Afriea.

Prepared in tle same way. Fibre cqual to K. reeurvata.

LXXVII. - Kniphofia Reculzata (Moore) syn. 'Tritoma reeurvata (Ker). "Reeurved-leaver 'Toreh Lily" or "Flamo Flower." Order Liliacece. South Afriea.

This quiek-growing perennial sueeeeds admirably in the colonies. Its long recurved leaves are very rich in fibre, of fair strength and quality, and is very easily prepared by boiling the leaves for, say, two hours, and then seraping. The writer lays claim to being the first to bring the Kniphofias nnder notice as fibre-produeing plants. In 1874-5 samples were prepared for the first time in his laboratory, as also the first examplo of Sparmannia fibre and others, and forwarded to several cxhibitions. 'The fibre of any of the Kniphofias ean be made ready for market in a few hours from the time the leaves are eut from the plant. They are readily multiplied by root division, and would yield at least two crops of leaves in a year with fairly good eultivation.

LXXVIII.-Lagunaria Patersonir (G. Don). "Norfolk Island Cow-iteh Tree." Order Malvacece. New South Wales, Queensland, and Norfolk Island.

$A$ very beautifnl leafy tree, of pyramidal habit of growth. It bears pretty rose-eoloured Hibiseus-like flowers in great profusion. The fibre obtained from the bark by maeeration is of a fine texture, strong and glossy; it might be eonverted into the finer kinds of cordage, textile fabries, matting, \&e. Lagunaria fibre is placed in the third division by Professor C. R. Dorlge in his Eeonomie Classification, that is-" Fibres capablo of employment in the arts, or rised by natives eliefly in the manufaeture of cordage, twine, nets, \&e., sometimes woven into fabries or beaten into eloth or "tappa.'"

Bark stripped off the branches, steeped for ten days, and then scraped. If left longer the fibre seems to deteriorate.

LXXIX - Lavatera arborea (Linnæus). "Common Trec Mallow." Order Malvacece. Western Europe and North Afriea.

Like most of the order the plant is of quiek growth. The ribbon-like bast is produeed in greater abundanee than most malvaeeous plants, and has been highly reeommended for paper material. Prepared by the nsual proeess of maeeration for a period of ten to fifteen days, aceorling to age of wood. 
Spon says :- "The inner bark yields a strong fibre, somewhat coarse, but capable of manufaeture in to cords, ropes, and mats."

LXXX.- Lavatera Maritima (Gouan). "Sea Mallow." Order Malvacea. West Mediterranoan Region.

A hardy evergreen shrub of quick growth. The fibre which is obtained by maeeration for seven days is fine and silky, 3 to 4 feet long, and casily prepared by scraping and heekling.

Of its value Thomas Christy says :- "Worthy of eultivation on a large scale for the very beautiful and exeellent quality of its fibre."

"Savorgnan states that it is spontaneous in the environs of Nieo, in western Liguria, in Sardinia, \&e. Cortieal fibre, tenacious, used for eordage. Abundant, and does not doteriorate in salt water. Adapted to eoarse hemp eablos and marino uses." (Useful Fibre Plants of the World, Professor C. R. Dodge.)

LXXXI.-Lavatera oxbia (Linnæus). "Velvet Mallow." Order Malvacea. South Europe.

A quiek-growing perennial. The stalks yield a boautiful fibre by macerating for a period of five to ten days. A wellprepared sample resembles white horsehair. 'Two, or even three, crops eould be obtained in a year by good enltivation and liberal manuring. The second erop of stalks is fit for gathering ton weeks after the first eutting, when plants have beeome properly established.

LXXXI.—Lavatera triLoba (Linnaus). "Threc-lobed Tree Mallow." Ordor Malvacee. Spain.

Time for maeeration, ten days. The sample is a very poor one, as healthy branehes were not obtainable. Fibre very easy to prepare, and not unlike that of L. maritima.

LXXXII.-Lepidosperia exatius (Labillardiere). "Tall Sword Rush." Order Cypéracea. Vietoria, South Australia, and Tasmania.

A tall speeics, very plentiful in mountainous distriets, sometimes attaining a length of 7 or 8 feet. Possibly a good paper plint. 'The fibre is not so strong as that of L. gladiatum, the "Coast Sword Rush." It is diffieult of preparation, a remark which applies to most of the genera eomprising the Orders Cyperacece and Juncacece, by reason of the largo amount of siliea eontained in tho cuticle of the leaves and stems. Proeess, boiling for 24 lours, then seraped, dried, and heekled. 
LXXXIV.-Lepidosperma GLadiatum (Labillardiere). "Const Sword Rush." Order Cyperacece. Vietoria, New South Wales, South and West Australia, and Tasmania.

This rigid smooth-stemmed Sword Rush is nndoubtedly one of our best paper plants. The fibre is strong, but the leaves require boiling for 24 hours.

"Spon says it is nsed by the natives for baskets and fishing lines, and suggests that its only indnstrial use will probably be paper-making, for which purpose it is considered equal to Esparto." (Useful Fibre Ilants of the World, Professor C. R. Dodge.)

LXXXV. - Lmpidosperira Longrtudinate (Labillardicro). "Long-leaved Sword Rush." Order Cypercece. Vieloria, New South Wales, Sonth and West Australia, and Tasmania.

One of tho tall sword rushes, very plentifnlly distributed over the south-east portion of Vietoria, on marshy land, extending from the eaast to the hills. Like most of the genns it yields a good paper pulp. Same treatmentas I. gladiatum.

LXXXVI.-Malvastrum Capense (Gareke) syll. Malva Capensis (Linnæus). "Cape False Mallow." Order Malvacece. South Africa.

A handsome shrub of quick growth. Fibre obtained by maeeration for fourteen days. Similar to that of Lavatera arborea.

I.XXXVII.-Maoutra PuYa (Weddell) syn. Bohmeria Pnya (IIooker). "Nepanl Grass-eloth Plant, "Puya-fibre-plant," "Wild Hemp," or "Pua Hemp." Order Urticucece. Himalayas and Burmal.

Prepared in the same way as Bohmeria nivea and B. maerophylla.

LXXXV1II.-Morde BrColor (Stendel) syn. Dietes bicolor (Sweet). Iris bicolor (Lindley). "l'wo-colonred Mol"a" el "Butterfly Flag Iris." Order Iridece. South Afriea.

Fibre obtained by boiling for three hours, and then scraping. Similar to that of M. Robinsoniana.

LXXXIX.-Morea Edulis (Ker) var. longifolia (Baker). Syn. M. longilolia (Sweet). "Long-leaved Horæa." Order Iridece. South Afriea.

Prepared by boiling for three hours, and then scraping. Fibre coarse, like Astelia Banksii. Sample exhibited for the first time. 
XC. - Moral (Iris) Robinsoniana. (F. v. Mueller) "Wedding Flower." Order Iridece. Of Lord Howe's Island, S. Pacifie.

This magnifieent perennial grows to a lieight of more than 6 feet. The leaves are rich in fibre, espeeially the stout midrib, and probably it would prove valuable for paper-stoek. It is the largest known speeies of the genus, and in habit of growth resembles the nearly allied Pardanthus Chinensis. Fibre obtained by boiling for nine hours, and then scraping.

\section{XCI.-Musa Eissete (J.F. Gmelin). "Bruee's Great Abys- sinian Banana." Order Scitaminea. Tropieal Afriea.}

Fibre prepared by boiling for fourteen hours, and then seraping. "A sample prepared by Mr. Morris, at Jamaiea, yielded at the rate of 1.16 per eent. of the gross weight. The fibre was somewhat weak aul dull looking; it had none of the lustre of the best plantain fibre, and it was valned in London at $£ 12$ to $£ 14$ per ton." (Useful Fibre Plants of the World, Professor C. R. Dodge.)

XCII.-Pandanus Forsteri (C. Moore and Mueller). "Tent Tree," of Lord Howe's Island. Order Pandanec.

The sample of fibre prepared from this speeies was obtained by boiling for twelve hours.

XCIII.-Phomaun Cooknanum (Le Jolis) syn. P. Coleusoi (IIooker, fil.). "Cook's Flax Lily" or" "Wharaeki." Order Liliwcece. New Zealand.

Leaves boiled for twelve hours, and then scraped. Fibro mueh finer than P. tenax, not nearly so long in staple, but easily prepared.

XCIV.-Phormun Cookianum variegatum syn. P. Colensoi variegatım. "Cook's Variegated Flax Lily." Order Liliacece. New Zealand.

Prepared by boiling for ten hours, and then seraping. Sample represents 62 lcaves so treated.

XCV. - Phom "iunar tenax (Forster). "Common Phornium Fibre" or "New Zealand Flax Plant." Order Liliaceœ. New Zealand.

Proeess, boiling the leaves for fourteen hours, and then seraping. Sample represents the produet of 100 leaves. (Seo also Useful Fibre Plants of the Wrorld, Professor C. R. Dodge.) 
XCVI.-Phormium tenax variegatun. "Varicgated Phormium Fibre" or "New Zealand Flax Plant." Order Liliacece. New Zealand.

See note in the description relating to Agave Americana variegata in reference to this variety.

Fibre prepared by boiliug for ten hours, and then scraping.

Sample represents the product of 77 leaves.*

XCVII.-Pinelea clavata (Labillardiere). "Club-flowered 'Tough Bark." Order Thymelacacece. Western Australia.

Yiclds a very fine bast. The fibre is obtained by stripping the bark from stems of trunk and branches, and scraping them when in the natural grecn state. 'The shrub grows to 10 or 12 feet.

XCVIII.-Plagianthus betulinds (A. Cunningham). "Ribbon Tree" or "New Zealand Lace-bark 'T'ree." Ordor Malvacece. New Zealand.

A hardy evergreen birch-like troc, growing to an ultimate height of 80 feet. From the bark a beautiful lace-like bast is obtained by maccration, closely assimilating to that furnished by Hoheria populnea, the "Otago Ribbonwood"; in fact, it is almost impossiblc to distinguish between the two when placed side by side. Like the latter, the Plagianthus is sometimes called "Ribbon Tree" from its similarity of bark.

Sample No. 1, ten days' maceration.

No. 2, fifteen days', taken from older wood than sample No. 1, bark stripped from branches and soaked in water.

No. 3 was obtained from dead branches.

XCIX. - Plagiantius pulchellus ( $\Lambda$. Gray) syn. Sida pulchella (Bonpland). "Victorian Hemp Bush." Order Malvacew. Victoria, Ner South Wales, and Tasmania.

A pretty shrub or small slender tree. It is almost invariably found growing on the banks of rivers, creeks, \&c.

Prepared in a similar way to "Jute-fibre," and requires about the same time for steeping. Supposed to be equal to "Queensland Hcmp" (Sida rlombifolia), and possesses the advantage of being much louger in staple. It can be obtrined 8 feet in length if necessary. The plant, which is of quick growth, is usually propagated by seed. On marshy land, subject to partial inundation, it shonld pay for cultivation. Fibre adapted for weaving

\footnotetext{
* For full and complete information regarding New Zealand Flax, see Sir James Hlector"s instructive pamphlet, Phormizm tenax as a Fibrous Plant, and edition, 1889 : Published by the New Zealand Government.
} 
into eloth, and may also be converted into ropes, eordage, twine, \&c. The present sample was obtained by maeeration for nine days.

Professor C. R. Dodge, in his Useful Fibre Plants of the World, refers to it thus:- "The bark is of a beautiful lace-like tcxturc, tearing into shrcds with greatest ease, but flexible and strong. According to the Treasury of Botany the tree is called Akaroa by the Ncw Zealanders, who extract a fibrous material from the young branches, known as New Zealand eotton, which is not only fine, but exceedingly strong, though resembling flax or hemp rather than cotton. The fibre of the ribbon treo is utilized in the nnanufaeture of fishing lines and nets, and to some extent for cordage and paper."

C.-Pon caspitosa (Forster) syn. P. australis (R. Brown). "Anstralian Meadow-Grass" or "Wiry Grass." Order Graminece. Victoria, New Soutlı Wales, Queonslaud, \&e.

A coarse perennial grass, whieh affords a fibre of fair quality by boiling for a period of six to eight hours. It is an excellent paper-stock, and with proper appliances might rival the "Esparto" or "A tocha Grass" (Stipa tenacissima) of the Spanish Peninsula. It is very plentiful on the rich alluvial dlats bordering on rivers, crceks, and tca-tree (Melalenca) swamps, where it grows in largo tussocks, and, when not eaten down by stoek, attains a height of nearly 4 fcet.

CT.-Schandus brevifolius (R. Brown). "Cord Rush of Victoria." Order Cyperacece. Victoria, New South Wales, Queensland, South and West Australia.

A wiry tufted rush-like perennial, very plentiful along the eoast and for some distanee inland, especially in the soutl-east portions of our eolony. It furnishes a fine fibre of considerable strength, not unlike that obtained from several species of Sansevieria, known as "Bowstring Hemp," and is also a valuable paper-plant. The mode of preparation is by boiling for about nine hours, after which the pulpy matter may be separated from the filaments either by washing or by pressure.

CTI-Scirpus noposus (Rottboell) syn. Isolepis nodosa. (R. Brown). "Knotted Club Ruslı" or "Wiwi." Order Cyperacece. Australia, Tasmania, Now Zealand, \&e.

A rush-like tufted perennial, plentifully distributed throughout Australia, usually along the eoast-line, and adjacent to water on rather poor sandy soils. It forms a good paper-stoek, but as a fibre-plant for other purposes is comparatively useless. Prepared by boiling for twelve hours, then scraped, dried, and heckled. 
CiII.-Sparunania Africana (Linnæus, fil.). "Common African Hemp Bush." Order Tiliacece. South Africa.

This handsome quick-growing shrub attains a lieight of 10 to 12 feet. It delights in a rich sandy loam ; and is quite at home in Victoria. By good cultivation and a liberal water supply during the hot season, it grows so rapidly here that two crops of "canes" at least can be obtained in a year. The bark, more especially that of the young branches or shoots, is very rich in fibre of fine texture. For many purposes it is considered by some experts equal, if not superior, to "Ramie" or "Chinese Grass-cloth" fibre. In appearance it resembles jute-fibre, but is supposed to be superior in some respects. Professor C. R. Dodge, in speaking of the sample of Sparmannia fibre (the first of its kind ever prepared), which was forwarded from these gardens by me to the Philadelphia Exhibition (1876), says :--"'The fibro is of a beautiful silvery-grey colour, when it has been properly prepared. Some of the filamonts of this sample are brilliant and lustrous, and it possesses considerable strength; in fact, secms almost eqnal to China grass in tenacity. He places it in the second division in his Economic Classification of Fibres."

In his Useful Fibre Plants of the World, lie also says:"The advantages which Sparmannia has over all other fibre plants, and which elevates it to the highest rank of agricultural products, are, that it is perennial, it is one of the very best forage plants in existence, its enormous yield, both of fodder and fibre, the great strength and dazzling whiteness of the fibre, the facility with which it takes dyes, and the extremely low prices at which it can be produced making it accessible even to the paper manufacturer." (Jean Roth.)

Commercial value of this fibre quoted to me at from $£ 17$ to $£ 17$ 10s. per ton in London.

Preparcd by maceration, young branches fiftecn days, older branches 21 days.

CIV. - Sparmannia Africana, Flore-pleno. "Doubleflowered African Hemp Bush." Order Tiliacea. South Africa.

Probable yield of fibre about 4 tons per acre. Commercial value same as the preceding.

Sample No. 1, young wood, three weeks' maceration.

Sample No. 2, older wood, four weeks' maceration.

Sample No. 3, much older wood, six wecks' maceration.*

\footnotetext{
* The use of Sparmannia Africana as a fibre plant was first discovered by the writer in 1873 , and the first sample ever exhibited was, as stated, sent from the Melbourne Botanic Gardens to the Centennial Exhibltion of l'hiladelphia, 1876.
} 
CV.-Spinkalcea umbellata (G. Don). "Umbel-flowered Globe Mallow." Order Malvacece. Mexico.

A bcantiful and ornamental flowering shrub of qnick growth, attaining a height of 10 fect. Fibre prepared by maceration for seventeen days.

CVI.-STerculta acerifolia (A. Cunningham) syn. Brachychiton acerifolins (F. v. Mueller). "Flame Tree" or "Lace Bark-tree" of New South Wales. Order" Sterculiacece. New Soutl Wales and Quccusland.

A lofty oruamental tree, bearing a profusion of brilliant scarlet flowers, from which fact it derives its common name "Flame Tree." The bark is very thick, and is composcl of numerous laycrs of beautiful lace-like ribbons, which arc easily separated by maceration for a period of 20 to 27 days. The young bark is more readily prepared than that of the stem and large branches. It is supposed to be equal, if not superior, to Cuba bast, which is composed of the inner bark of the "Mountain Mahoe," Hibiscns elatus (Swartz). It can be woven into coarsc cloth, plaited into hats and bonncts, converted into ropes, corlagc, and matting, \&c. It should make good ships' hawgers on accont of its clasticity, and as watcr does not appear to have an injurious effect upon it. The refusc after heckling would form no mean substitute for horsehair in stuffing mattresses, sadules, \&c. It can also bo ntilizcl as admixturo in paper-making. From tho seed-pods a rich brown dye is obtained.

CVII.-Stercelia diversifolia (G. Don) syn. Brachychiton popnlneus (R. Brown). "Victoria Bottle Treo" or "Currijong Tree" of New South Wales. Order Sterculiacece. Victoria, New South Wales, and Quecnsland.

A handsome lcafy tree of pyramidal habit, attrining a lieight of 50 feet or more. Having a thick swollen trunk it is called "Bottle Treo" by some of the settlers. The Aborigines name it "Currijong," which worl would seem to imply "tough," as it is applicel to various Pincleas and other plants having tough barks, which are used by them for making fisling lines, baskets, \&c. 'I'lue fibre of the inner bark of this species is similar to that of the preceding, but coarser in texturc, and of a darker colonl. It would make strong ropes, matting, \&c. This bark takes mucb longer in retting than that of the "Flame Tree."

CVIII.-Sterculia Lurida (F. v. Muelier) syn. Brachychiton luridus (C. Moore). "Sycannore of Australia" or "Hat Tree." Order Sterculiacece. New South Wales and Qucensland.

A tall handsonc tree, with dark-green dceply-lobed lcavcs, somewhat like thoso of the "Flame Tree." The bark affords a 
good fibre suitable for ropes, eordage, \&c. 'The process of maceration extends sometimes to five or six weeks.

CIX.-Typha Angustifolia (Linnæus). "Native Bullrush" or "Cat's-tail." Order Typhacece. Australia, Tasmania, New Zealand, Europe, \&c.

This cosmopolitan aquatic peremnial is too well known to neod description. It is very plentiful in Victoria and the other Australian colonies, on the banks of strenms and fresli-water lagoons. Furnishes a first-class material for paper-making, and a fibre of fair strength and fineness may be manufactured from the leaves.

Prepared by a boiling process, which occupies four hours; afterwards it is scraped and heckled.

Sample prepared from 100 leaves.

CX.-.Xerotes longtalia (R. Brown). "Native 'Tussock Grass" or "Mat Rush." Order Juncacere. Victoria, New South Wales, Queensland, \&c.

A tufted perennial, widely dispersed throughout the colonies, espccially on plains and open country subject to floods, or in the neighbourlood of water. The leaves attain a length of 3 or 4 feet; they furnish a valuable paper-pulp. As a fibre-plant for any other purpose, however, it may be considered of little value. Prepared by boiling for twelve hours, and the usual scraping.

"It is reckoned as the best indigenous substitute for 'Isparto" for paper-making." (Spon). 'The culms are used by the Yarra tribe of south-eastern Australia for manufacturing baskets. (Useful Fiüre Plants of the World, Professor C. R. Dodge.)

CXI.-YUCCA ALOHOLIA (I.innaus). "Aloe-leaved Adam's Needle" or "Dagger-leaf." Order Liliacece. North America and West Indies.

A plant well known in Australian gardens of any pretensions, being extensively planted for sccnic effect, in conjunction with Cordylines, Doryanthes, Agaves, Dasylirions, and such like. It is a good fibre-plant, and, liko many other species of the genus, succeeds on the poorest soils, and is of moderately quick growth. 'The fibre is suitable for ropes, cordage, and coarsc cloth, and possesses great strength. In appearance and texture it resembles Agare fibre. It is rery simply prepared, either by maceration, hy erushing the leaves between fluted rollers, or by boiling; the latter operation takes fonr hours, after which the cuticle comes away readily by scraping. The sanple is the product of 360 leares so treated. 
CXII.--YUCCA ALOIFOLIA (Linnæus) variegata. "Variegated Dagger-leaf." Order Liliacece. Mexieo.

Fibre prepared by boiling for six hours, and then seraping. Sample produeed from 227 leaves.

CXIII.-YUCCA Filamentosa (Linnæus). "Thread-bearing Mound Lily," or "Bear Grass." Order Liliacece. North America.

A good fibre-plant of easy cultivation. Prepared by boiling for three hours, and seraping. Professor C. R. Dodge, in his Useful Fibre Plants of the World, gives a lengthy and interesting aecount of this Yueea as a fibre-plant.

CXIV.-Y YCCA FLEXILIS (Carriere) syu. Y. stenophylla (Hort). "Flexible Yucca." Order Liliacece. Mexieo.

Fibre produced by boiling the leafage for four hours, and then seraping. 'The sample is the produet of 350 leaves so treated.

CXV.-YuCCa Gloriosa (Linnæus). "Common Mound Lily" or "Petre Hemp." Order Liliaced. North Ameriea.

This magnificent plant furnishes the "Petre Hemp" of Mexieo, where it is manufactured into ropes, eordage, paeking eloth, \&c., and is extremely durable. "Undonbtedly one of the best of the American fibre plants." Fibre prepared by boiling for six hours, and then seraping. Sample the produet of 262 leaves.

CXVI.-YuCCA GLoRIosa variety superba (Baker). Syn. Y. superba (Haworth). "Superb Mound Lily." Order Liliacece. North Ameriea.

A variety of the preeeding. The fibre is of a similar quality, and is prepared in the same manner.

CXVII.-Yucca Guatemalensis (Baker) syn. Y. Ghiesbreelitii (Hort). "The Large Broad-leaved Mound Lily." Order Liliacece. Mexieo and Guatemala.

The fibre exhibited was obtained by boiling for twelve hours, and then seraping.

CXVIII.-Yucca Treculiana (Carriere) syn. Y. agavoides (Hort). "Trecul's Dagger-leaf." Order Liliacece Mexieo.

Fibre prepared by boiling for six hours, and seraped. Not so easily prepared as Y. aloifolia or $\mathrm{Y}$. gloriosa. Similar in quality - to Y. Guatemalensis. 
CXIX.-Yucca Whipplei (Torrey) syn. Y. Californica (Lemaire). "Whipple's Yucca" or "Mound Lily." Order Liliacece. California.

The fibre of this species is exceedingly fine, and very easily prepared after boiling for six hours, then scraping with a blunt knife. Samplc the product of 250 leaves. Professor C. R. Dodge says of this plant in Useful Fibre Plants of the World"Another Californian species of Yucca, samples of fibre and cordage of which have been received, collected by Dr. E. Palmer, who states that the leaves yield a very soft white fibre, which is capable of being madc into very nice thread. Indians use this fibre to form a padding for their horse blankets, the outer part of which, being made of the fibre from the Yucca baccata, is very rough. A wooden needle is threaded with twine made from the same fibre, and the lining is firmly quilted to the saddle blanket, forming a soft covering, without which it would injure the animal's back." 


$$
\begin{aligned}
& \text { p } 6325 \\
& \text { G956 }
\end{aligned}
$$


$\operatorname{mon} 0584$

(1) 1958

$=$

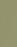


<smiles>[CH]C</smiles> 